University of Nebraska - Lincoln

DigitalCommons@University of Nebraska - Lincoln

USDA Wildlife Services - Staff Publications

U.S. Department of Agriculture: Animal and Plant Health Inspection Service

8-1-2021

\title{
Nicarbazin as an oral contraceptive in eared doves
}

Lourdes Olivera

Instituto Nacional de Investigación Agropecuaria - INIA Uruguay, lourdes.m.olivera@gmail.com

Silvia Pereyra

Instituto Nacional de Investigación Agropecuaria - INIA Uruguay

Georgget Banchero

Instituto Nacional de Investigación Agropecuaria - INIA Uruguay

Guillermo Tellechea

Instituto Nacional de Investigación Agropecuaria - INIA Uruguay

Jorge Sawchik

Instituto Nacional de Investigación Agropecuaria - INIA Uruguay

Serowexthpage fordadflitionalarkthort:https://digitalcommons.unl.edu/icwdm_usdanwrc

Part of the Natural Resources and Conservation Commons, Natural Resources Management and

Policy Commons, Other Environmental Sciences Commons, Other Veterinary Medicine Commons,

Population Biology Commons, Terrestrial and Aquatic Ecology Commons, Veterinary Infectious Diseases

Commons, Veterinary Microbiology and Immunobiology Commons, Veterinary Preventive Medicine,

Epidemiology, and Public Health Commons, and the Zoology Commons

Olivera, Lourdes; Pereyra, Silvia; Banchero, Georgget; Tellechea, Guillermo; Sawchik, Jorge; Avery, Michael L.; and Rodríguez, Ethel, "Nicarbazin as an oral contraceptive in eared doves" (2021). USDA Wildlife Services - Staff Publications. 2486.

https://digitalcommons.unl.edu/icwdm_usdanwrc/2486

This Article is brought to you for free and open access by the U.S. Department of Agriculture: Animal and Plant Health Inspection Service at DigitalCommons@University of Nebraska - Lincoln. It has been accepted for inclusion in USDA Wildlife Services - Staff Publications by an authorized administrator of DigitalCommons@University of Nebraska - Lincoln. 


\section{Authors}

Lourdes Olivera, Silvia Pereyra, Georgget Banchero, Guillermo Tellechea, Jorge Sawchik, Michael L. Avery, and Ethel Rodríguez 
Review

\title{
Nicarbazin as an oral contraceptive in eared doves
}

\author{
Lourdes Olivera $^{\mathrm{a}, *}$, Silvia Pereyra ${ }^{\mathrm{b}}$, Georgget Banchero ${ }^{\mathrm{b}}$, Guillermo Tellechea ${ }^{\mathrm{a}}$, \\ Jorge Sawchik $^{\mathrm{b}}$, Michael L. Avery ${ }^{\mathrm{c}}$, Ethel Rodríguez ${ }^{\mathrm{d}}$

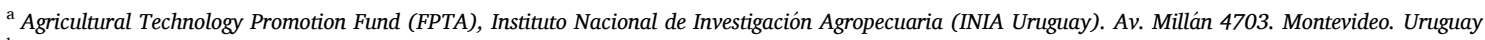 \\ ${ }^{\mathrm{b}}$ Instituto Nacional de Investigación Agropecuaria (INIA Uruguay), Ruta 50, Km 11. Colonia, Uruguay \\ ${ }^{\mathrm{c}}$ USDA APHIS National Wildlife Research Center, Washington, D.C., USA \\ ${ }^{\mathrm{d}}$ Dirección General de Servicios Agrícolas. Uruguay. Av. Millán 4703. Montevideo, Uruguay
}

\section{A R T I C L E I N F O}

\section{Keywords:}

Zenaida auriculata

Reproductive control

\begin{abstract}
A B S T R A C T
Eared doves (Zenaida auriculata) are responsible for substantial losses in cereal and oil crops as well as in dairy and feedlot production in the southern cone of South America. Various strategies have been shown to be effective in reducing damage at the farm scale, but in some scenarios, it is necessary to also incorporate population control methods due to excessive bird population size. An alternative approach to reduce pest bird populations is the use of contraceptive methods, minimizing the impact on the environment and non-target populations. Nicarbazin is registered in the United States as a contraceptive for Branta canadensis and Columba livia. The aim of this study was to measure the effect of nicarbazin on the reproductive performance of eared doves in captivity. This study included eleven caged pairs of nesting eared doves in three experimental phases (pre-treatment, treatment, recovery). Each pair was exposed to nicarbazin bait for $4 \mathrm{~h}$ per day. The contraceptive used was OvoControlP ${ }^{\circledR}$ ( $0.5 \%$ nicarbazin) ground with a millstone into particles of $0.5-3.0 \mathrm{~mm}$. Daily bait consumption and reproductive variables per pair (egg laying and 14-day-old fledgling) were recorded, and levels of $4,4^{\prime}$ dinitrocarbanilide were measured in feces and unhatched eggs. Median consumption was $4.2 \mathrm{~g}$ of bait/pair/ day. We observed a $62 \%$ reduction in the number of viable eggs and successful nestlings in the treatment phasein contrast to pre-treatment $(V=36 ; p=0.006)$. There were no significant differences $(V=0 ; p=1)$ in the number of viable eggs between the pretreatment and recovery phases. Median daily bait consumption by pairs producing zero or one nestling ( 4.4 and $5.0 \mathrm{~g} /$ pair/day respectively) was significantly higher than that of pairs that had two nestlings $(3.4 \mathrm{~g} /$ pair $)$ during the treatment phase $(\mathrm{t}=2.0 ; \mathrm{p}=0.002)$. Nicarbazin was effective in reducing reproductive performance of eared doves, and its effect was reversible when the treatment finished.
\end{abstract}

\section{Introduction}

Wild birds cause economic damage to agriculture crops throughout the world. Resources impacted include aquaculture (Otieno, 2019), fruit and berry crops (Tracey et al., 2007), seeds and grain crops (Klosterman et al., 2011; De Mey and Demont, 2012) and livestock feed (Carlson et al., 2018).

Farmers use various methods to reduce bird damage, including modified agronomic practices, bird-resistant varieties (Linz et al., 2015), auditory and visual scare techniques (Bishop et al., 2003) and chemical repellents (Werner and Avery, 2017). Such non-lethal techniques applied properly may be effective in reducing damage on a farm scale. However, in some situations the depredating bird population is so great that it is necessary to complement non-lethal control with population management practices as part of an integrated management strategy (Avery, 2014).

Lethal control is often practiced to reduce pest bird populations, but this approach has been found to be costly, ineffective and detrimental to the environment, especially to non-target species (Linz et al., 2015). An alternative approach to reduce pest birds populations would be the use of contraceptive methods that minimize the impact on the environment and on non-target populations (Avery, 2014). Field applications of nicarbazin baits will address factors such as location, timing, duration, and amount of bait deployed to reduce likelihood of exposure of non-target species to the contraceptive.

In several South American countries, eared doves (Zenaida auriculata) cause damage to cereal and oil-production crops (Dardanelli et al., 2016; Rodríguez et al., 2011; Bucher and Ranvaud, 2006; Robles et al.,

\footnotetext{
* Corresponding author.

E-mail address: lourdes.m.olivera@gmail.com (L. Olivera).
} 
2003; Bruggers et al., 1998) and food losses in dairies and feedlots. For example, in Uruguay losses up to $49 \%$ have been documented along crop edges in soybean fields (Bou et al., 2016). In Argentina, losses range from $5 \%$ to $40 \%$ in sunflower (Vitti and Zuil, 2012) and up to $16 \%$ in soybean crops (Scalora et al., 2013). Furthermore, eared doves consume as much as $22 \mathrm{~g}$ of cattle ration/bird/day in Uruguayan cattle feedlot systems (Olivera et al., in press). Consequently, eared doves represent a major constraint for agricultural producers in Uruguay and elsewhere in the region.

In Uruguay, control strategies have been focused on preventing damage and protecting crops at the farm level, such as chemical and physical repellency methods (Rodríguez et al., 1995, 2011). Spraying problems and high cost/benefit ratios (Olivera et al., 2020) limit the use of these methods. Also, effectiveness is affected by timing and regularity of application, availability of alternative food for birds, and bird population size (Avery, 2014; Rodríguez et al., 2011). Additionally, agricultural expansion in recent decades has caused increased conflicts with depredating birds, especially eared doves (Tellechea and Rodríguez, 2016) which has reduced the possibility of effectively controlling bird damage with standard crop prevention and protection techniques. In such cases, crop protection strategies might require a population reduction component (Avery, 2014). New alternatives should be explored given the economic consequences of avian damage and the limitations to its control.

Although contraceptives have been evaluated for population management in bird species such as monk parakeet Myiopsitta monachus (Rodríguez and Tiscornia, 2002; Yoder et al., 2007), rock pigeon Columba livia (Albonetti et al., 2015; Avery et al., 2008), Canada geese Branta canadensis (Bynum et al., 2007) and quail Coturnix coturnix (Yoder et al., 2004), their effectiveness has not been investigated in eared dove.

Avian contraceptive research has focused on two compounds: 20,25-

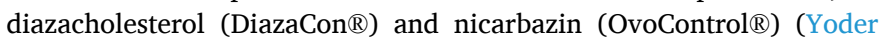
and Miller, 2006; Kirkpatrick and Turner, 1985). Nicarbazin was registered in the United States in 2005 as OvoControlG ${ }^{\circledR}$ for Canada geese and OvoControlP ${ }^{\circledR}$ for rock pigeon in 2007 (Fagerstone et al., 2008). The compound is a bimodal salt consisting of two components: 4 , 4'-dinitrocarbanilide (DNC) (active ingredient) and hydroxy-4, 6-dimethylpyrimidine (HDP, adjuvant). The adjuvant is added to increase DNC absorption at the intestinal level (Cuckler et al., 1955). Nicarbazin acts inside the eggs and increases the permeability of the yolk membrane causing the yolk and the albumin to mix, interrupting embryo development (Yoder et al., 2006a). When nicarbazin was provided to rock pigeons, the number of chicks was reduced by $59 \%$ and in the case of Canada geese eggs hatching decreased by 56\% (Bynum et al., 2007; Avery et al., 2008).

In a previous assessment of the possible role for chemosterilants in integrated pest bird management programs, Feare (1991) concluded that the contraceptive method was not effective in reducing immediate damage. We agree that contraception should not be viewed as a short-term solution to bird damage in crops. Instead, it is best viewed as a method for long-term population reduction which might be an effective tool as part of a multi-year integrated approach to bird damage management in Uruguay (Avery, 2014).

Recent progress in the USA and Europe on avian contraceptives (Albonetti et al., 2015; Fagerstone et al., 2010; Avery et al., 2008) and the need to add new strategies to mitigate damage caused by eared doves prompted this study. Our aim was to measure the effect of nicarbazin consumption on the reproductive performance of eared doves in captivity. Our hypotheses were that (1) nicarbazin would reduce the numbers of viable eggs and successful nestlings (14 days after hatching) relative to reproductive performance without treatment; (2) since the nicarbazin ingested by birds is transported through blood and deposited in the eggs, it would be detected in unhatched eggs; and (3) the effect of the contraceptive is reversible, so after discontinuing nicarbazin consumption the reproductive variables would be restored to pre-treatment levels.

\section{Materials and methods}

\subsection{Description of aviaries and cages}

Experiments were conducted from April 2019 to July 2020 in two aviaries at the Ministry of Livestock, Agriculture and Fisheries (MGAP), Montevideo, Uruguay.

A quarantine aviary, with natural light conditions and controlled temperature (from $18{ }^{\circ} \mathrm{C}$ to $25^{\circ} \mathrm{C}$ ) was used as the first step with the aim of achieving a standard optimal physical condition in all doves and to prevent diseases. It had 22 individual cages $(40.5 \mathrm{~cm}$ long, $23.5 \mathrm{~cm}$ high, $24.0 \mathrm{~cm}$ deep) made of steel wire mesh 1.5 by $13.0 \mathrm{~cm}$ in section. Each cage had two external metal feeders, a drinker, and a perch stick.

The experimental aviary, used during the second phase, also had natural light and controlled temperature (from $12{ }^{\circ} \mathrm{C}$ to $32{ }^{\circ} \mathrm{C}$ ). It comprised 26 cages ( $1.20 \mathrm{~m}$ long, $1.20 \mathrm{~m}$ high, $0.85 \mathrm{~m}$ deep) made of braided netting of $1 \mathrm{~cm} \times 1 \mathrm{~cm}$ section and steel wire floor. Each cage was provided with branches, pine needles and three types of artificial nests: platform (metal netting), plastic open (cup-shaped) and plastic closed nest (simulating a hollow). Materials for nest construction were offered daily.

\subsection{Birds}

A total of 42 adult doves were caught using two "walk in" funnel bird traps ( $1 \mathrm{~m} \times 1 \mathrm{~m}$ side $\times 0.15 \mathrm{~m}$ high steel wire mesh) in an industrial dairy farm located in Durazno, Uruguay $\left(33^{\circ} 20^{\prime} 27.58^{\prime \prime} \mathrm{S}\right.$, $\left.56^{\circ} 33^{\prime} 50.40^{\prime \prime} \mathrm{W}\right)$. Birds were transported to the quarantine aviary and maintained there for 22 days.

The health routine at the quarantine phase included providing water with the following drugs: sufametazine and sulfaquinoxaline sodium $2.0 \mathrm{~mL}^{-\mathrm{L}^{-1}}$ for six days (Nitro Sulfa Aviar, Laboratorios Sur, Montevideo, Uruguay); metronidazole 4.6 g. $\mathrm{L}^{-1}$ for five days (formulated by veterinary "Garibaldi", Montevideo, Uruguay); piperazine adipato 4.0 g.L $\mathrm{L}^{-1}$ one day (Piper Vetcross, Portinco S.A, Montevideo, Uruguay); and vitamins and amino acids $1.0 \mathrm{~mL} . \mathrm{L}^{-1}$ for two days (Promotor L, Calier, Montevideo, Uruguay). Food and water were offered ad libitum. Diet in this period consisted of a feed ration made of equal parts of wheat, sorghum, and cracked corn grains.

During the experiment, doves were fed a diet containing $13.33 \%$ of sorghum, $13.33 \%$ cracked corn, $13.33 \%$ wheat and $13.33 \%$ sunflower grains, each: $6.67 \%$ of foxtail-millet, $6.67 \%$ millet, $6.67 \%$ birdseed, $6.67 \%$ rapeseed, $6.67 \%$ peeled oats, $6.67 \%$ flax, $6.67 \%$ poultry pellets (Molino San José, San José, Uruguay). Magnesium biocalcium (CaCO3 96\%; Mg3 (PO4)2 1\%; ZnSO4 1.7\%; BioLab, Montevideo, Uruguay) was added to the mixed feed ration $\left(8.75 \mathrm{~g} \cdot \mathrm{Kg}^{-1}\right)$.

All procedures with birds were carried out in accordance with Uruguayan Law $\mathrm{N}^{\circ} 18,611$ regarding the use of experimental animals. The protocols were approved by the Ethics Committee for the Use of Experimental Animals of the General Directorate of Agricultural Services (MGAP), form 01. No birds died in the course of the experiments.

\subsection{Contraceptive bait}

The product used was OvoControlP ${ }^{\circledR}$, registered for rock pigeons in all states of United States of America (except New Hampshire), by Innolytics LLC (Rancho Mirage, United States). The formulated cylindrical granules (ca.7.0 $\mathrm{mm}$ long and $5.0 \mathrm{~mm}$ diameter) contained $0.5 \%$ nicarbazin. Pellets were cracked with a millstone (Orientsun Model $\mathrm{N}^{\mathrm{O}}$ 500 hand mill) into particles of $0.5-3.0 \mathrm{~mm}$.

The amount of contraceptive bait offered was estimated based on the recommendation for rock pigeons (Avery et al., 2008). As the bait was cracked, it comprised variable particles sizes. Consequently, two additional grams of the contraceptive bait were added to the estimated dose 
to anticipate that the eared doves might have preferences for some specific particle sizes (Olivera et al., in press).

\subsection{Variables measured}

The experimental unit was the dove pair. Contraceptive consumption (C) was estimated per pair and per day as $C=W i_{c o r}-W f$. Wf feeder final weight. $W i_{c o r}$ : feeder initial weight as a function of the variation measured in an extra feeder (ef) without access to birds. This was used to record fluctuations in weight due to loss or gain of humidity, calculated as: $W i_{c o r}:\left(W i * W f_{e f}\right) / W i_{e f}$, being $W i$ : initial weight of the bird feeder, $W i_{e f}$ : initial extra feeder weight, $W f_{e f}$ f final extra feeder weight.

For every dove pair, the following reproductive variables were recorded: number of laid eggs, viability of each egg and number of flying 14-day-old nestlings. The amount of $4,4^{\prime}$ dinitrocarbanilide (DNC) was quantified in fecal matter when eggs were laid and in unhatched eggs. Samples were stored at $-18{ }^{\circ} \mathrm{C}$. DNC quantification was done according to Stahl and Johnston (2002) and Stahl et al. (2003).

\subsection{Experimentation phases}

\subsubsection{Pairing and maintenance}

Individuals were sexed following Bucher et al. (1981) and by polymerase chain reaction (PCR) amplification at Institute for Biological Research "Clemente Estable" (IIBCE) using wing feathers. Twenty-one male and female pairs were randomly arranged and their behavior was observed to determine their compatibility. In case the pair was not compatible, new pairings were arranged. In some cases, we put two females and one male together in a cage. In other cases, we connected two cages with one pair each, until suitable mates were found. Then, the extra female was removed from the cage and compatible pairs were maintained for the experiment.

Reproductive behaviors such as male vocalizations, mutual grooming, or material collection for nest construction were daily monitored. After four months in captivity, 11 pairs started their reproductive phase successfully. Four pairs laid eggs that were not viable and six pairs did not lay eggs throughout the study period.

\subsubsection{Pre-treatment phase}

The purpose of this phase was to measure the reproductive variables of the species, represented by 21 pairs, without contraceptive effect. It began when the first egg was laid. Six days later presentation of the contraceptive started. This was to ensure that the levels of nicarbazin in the blood would be effective the next time the females ovulated. The phase ended when the flying nestlings were 14 days old. At egg laying, fecal matter produced by each pair in one day was collected for DNC analysis from pans placed under their cage.

\subsubsection{Treatment phase}

The objective of treatment phase was to measure the effect of contraceptive consumption on reproductive variables. It started when the chicks from the previous phase (pre-treatment) were taken out of the parental cage. The contraceptive bait supply to each pair continued from the previous phase. Food was offered at 9:30 a.m. in two plastic feeders ( $8.5 \mathrm{~cm}$ in diameter and $4.5 \mathrm{~cm}$ high), with $8 \mathrm{~g}$ of contraceptive each. During a 4 hr-period the contraceptive was available without any other alternative food. At 01:30 p.m. the remaining bait was collected and weighed as was spillage (feeder final weight). Subsequently, $11 \mathrm{~g}$ of maintenance feed were offered. This amount was then increased to $14 \mathrm{~g}$ when the pre-treatment chicks were 10 days old. Additionally, an extra plastic feeder with $8 \mathrm{~g}$ of contraceptive was added without access to birds in order to record fluctuations in weight due to loss or gain of humidity.

The contraceptive bait supply was discontinued with the laying of at least one egg. If no eggs were laid for 21 days after the end of the pretreatment phase, the contraceptive routine was discontinued, and the treatment phase was ended. Fecal samples were taken for DNC analysis at egg laying or at the end of treatment phase.

If eggs from the treatment phase hatched, chicks were removed from the cage when they were 14 days old and the treatment phase ended. Non-viable eggs were removed from the nest five days after the calculated hatching date and the amount of DNC was measured.

\subsubsection{Recovery phase}

The recovery phase began when nestlings from the previous phase were removed from the parental cage or the treatment phase was concluded. It ended when the chicks were 14 days old. Only untreated food was offered during this phase. At egg laying, fecal samples were taken for DNC analysis.

\subsection{Statistical analysis}

The effect of the contraceptive was analyzed by calculating the median of reproductive traits and contrasting pre-treatment vs. treatment and pre-treatment vs. recovery. Wilcoxon range test was used to determine significant differences among treatments, in number of eggs and successful nestlings. Consumption median were compared with Kruskall-Wallis test, according to the number of nestlings in the treatment phase.

Associations among traits were also investigated. We were interested in the relationship between the median of daily and accumulated consumption of contraceptive and the number of successful nestlings produced. We tested linear correlations with Spearman and assessed the fit to other functions such as the second-degree polynomial. In addition, the association between DNC residues in feces and eggs, with the consumption of contraceptive was examined. In all cases, the Spearman's rank correlation coefficients were calculated.

\section{Results}

Levels of daily and accumulated consumption of nicarbazin bait varied among pairs of doves, in amount consumed and number of days the doves were exposed to the bait (Table 1). During the 7-week treatment period, median consumption of nicarbazin bait was $3.8 \mathrm{~g} /$ pair/ day, ranging from 2.9 to $11.8 \mathrm{~g} / \mathrm{pair} /$ day, with a coefficient of variation of $50.1 \%$ (Fig. 1). Since the contraceptive supply was interrupted at egg laying, the length of this period varied among pairs. Two pairs laid eggs in the fourth week after the contraceptive bait offer started. Five pairs did not lay eggs until the fifth week and two others completed their laying at the sixth week after supplying the contraceptive. Three pairs of doves did not lay eggs and therefore, the provision of contraceptive continued until the end of the treatment phase.

The number of eggs decreased marginally in the treatment phase compared to pre-treatment $(\mathrm{V}=6 ; \mathrm{p}=0.09)$. The number of viable eggs and successful nestlings produced under treatment decreased $62 \%$ compared to pre-treatment $(\mathrm{V}=36 ; \mathrm{p}=0.006)$ (Table 2). On the other

Table 1

Median consumption of contraceptive bait.

\begin{tabular}{llll}
\hline & $\begin{array}{l}\text { Accumulated } \\
\text { consumption } \\
\text { pair) }\end{array}$ & $\begin{array}{l}\text { Median } \\
\text { consumption } \\
\text { g per pair) }\end{array}$ & $\begin{array}{l}\text { Period of } \\
\text { consumption } \\
\text { (days) }\end{array}$ \\
\hline Median & 208 & 4.2 & 35 \\
Maximum & 327 & 5.9 & 43 \\
Minimum & 131 & 2.5 & 27 \\
Coefficient of & 29.1 & 23.9 & 17.6 \\
variation (\%) & & &
\end{tabular}

Eleven pairs of eared doves (Zenaida auriculata) were offered $16 \mathrm{~g}$ of contraceptive Ovocontrol ${ }^{\circledR}$ daily for $4 \mathrm{~h}$ in the morning with no alternative food. Accumulated consumption is the total intake of the pair during the treatment period. Median consumption was calculated considering each pair. Period of consumption is the number of days that the contraceptive was consumed. 


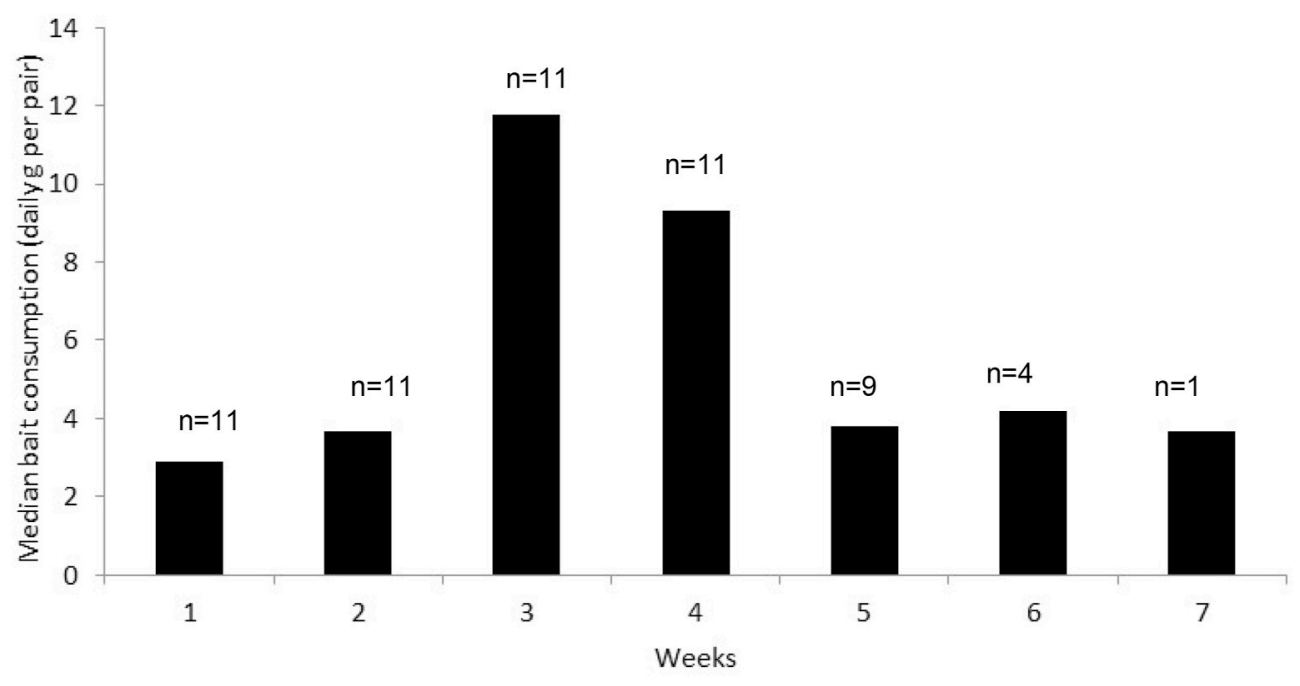

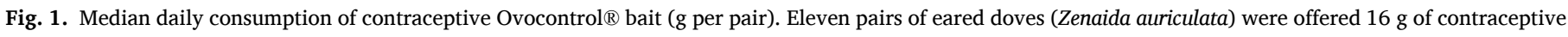
for $4 \mathrm{~h}$ in the morning without another food. The number of pairs in the treatment is indicated above each bar.

Table 2

Reproductive variables of pairs of eared doves (Zenaida auriculata) in the experiment.

\begin{tabular}{llll}
\hline & Pre -treatment & Treatment & Recovery \\
\hline Pairs (n) & 11 & 11 & 11 \\
Pairs that did not lay eggs & 0 & 3 & 0 \\
Number of eggs laid & $21^{\mathrm{a}}$ & $16^{\mathrm{a}}$ & $21^{\mathrm{a}}$ \\
Number of viable eggs & $21^{\mathrm{a}}$ & $8^{\mathrm{b}}$ & $18^{\mathrm{a}}$ \\
Number of unviable eggs & 0 & 8 & 3 \\
Number of successful nestlings & $21^{\mathrm{a}}$ & $8^{\mathrm{b}}$ & $18^{\mathrm{a}}$ \\
\hline
\end{tabular}

A reproductive cycle before the administration of the contraceptive Ovocontrol ${ }^{\circledR}$ (pre-treatment), during (treatment) and after its administration (recovery). Different letters in the same row indicate significant differences ( $\left.\alpha^{<} 0.05\right)$. Successful nestlings are those that reach 14 days of age.

hand, the number of eggs in the recovery phase did not differ from pretreatment $(\mathrm{V}=0 ; \mathrm{p}=1)$. Also, the number of successful nestlings decreased marginally in the recovery phase compared to pre-treatment $(\mathrm{V}=6 ; \mathrm{p}=0.07)$.

Consumption of treated bait by pairs of doves that produced zero or one nestling was significantly higher than that observed in pairs that had two nestlings in the treatment phase (Fig. $2 ; \mathrm{t}=2.0 ; \mathrm{p}=0.002$ ). There was no difference in consumption of treated bait between pairs with zero

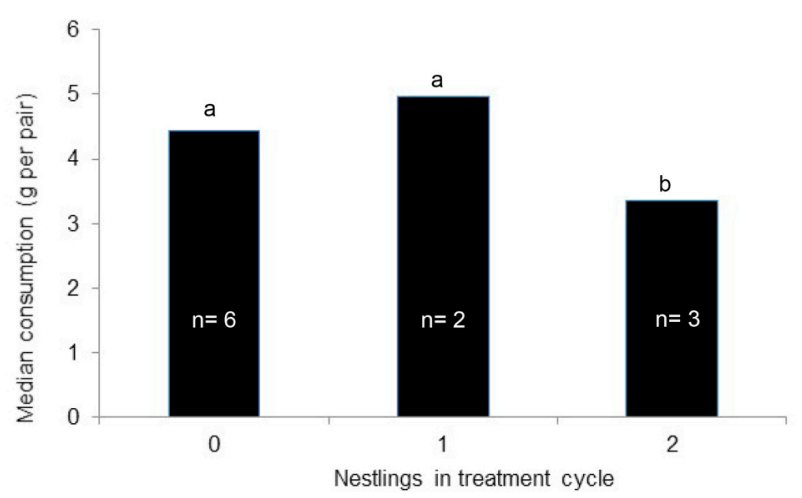

Fig. 2. Median daily consumption of contraceptive Ovocontrol ${ }^{\circledR}$ bait (g per pair) and standard deviation as a function of the number of nestlings produced in the treatment phase. The number of pairs of eared doves (Zenaida auriculata) in each category is indicated. Different letters indicate significant differences ( $\alpha$ $\leq$ 0.05). and one nestling in the treatment phase $(\mathrm{p}=0.24)$.

No relationship was found between successful nestlings in the treatment phase and median contraceptive consumption using either linear regression ( $r h o=-0.32 ; p=0.34$ ) or a second-degree polynomial function $\left(\mathrm{R}^{2}=0.29 ; \mathrm{p}=0.24\right.$; Fig. $\left.3 \mathrm{~A}\right)$. The number of nestlings did not have a linear association with the accumulated consumption of contraceptives (rho $=-0.50 ; \mathrm{p}=0.11$ ), which was better explained with a second-degree polynomial function $\left(\mathrm{R}^{2}=0.58 ; \mathrm{p}=0.03\right.$; Fig. 3B). The length of the period (days) in which the birds consumed contraceptive showed a non-significant linear correlation with the number of successful chicks (rho $=-0.55 ; \mathrm{p}=0.08$ ). However, a second-degree polynomial function was not significant $\left(\mathrm{R}^{2}=0.40\right.$; $\mathrm{p}=0.13$; Fig. $\left.3 \mathrm{C}\right)$.

The contraceptive residues (DNC - 4,4'dinitrocarbanilide) recovered from feces and unhatched eggs (Fig. 4) did not show a linear association with the median contraceptive consumption ( $r$ ho $=0.18 ; \mathrm{p}=0.59$ for DNC in feces; rho $=0.30 ; \mathrm{p}=0.62$ for DNC detected in eggs).

\section{Discussion}

Under our study conditions, nicarbazin reduced reproductive success in caged eared doves. The numbers of viable eggs and successful nestlings (14 days) in the treatment phase were significantly lower than those produced by the same birds in the previous phase without treatment. The magnitude of the reduction on successful nestlings in our study was similar to that described by Bynum et al. (2007) and Avery et al. (2008), who reported reductions in nestling numbers of $59 \%$ for rock pigeons and up to $56 \%$ in eggs hatching in Canada geese, respectively. Nicarbazin, used as contraceptive, has an effect on egg development at the time of onset of follicle development (Avery et al., 2008; Yoder et al., 2006a). Yoder et al. (2006a) found that nicarbazin increases the activity of lipoprotein lipase, reducing the amount of very low-density lipoprotein deposited in the follicle and consequently decreases the production of eggs and their weight.

The dose of nicarbazin that Avery et al. (2008) found to be effective for rock pigeons ranged between 90 and $120 \mathrm{mg} \mathrm{kg}^{-1}$ body mass/day. Based on the manufacturer's suggestions, we expected the dose of nicarbazin for eared dove would be approximately $1 / 3$ of that used in rock pigeons, equivalent to 11-15 mg of nicarbazin/dove/day. This dose could be achieved by the consumption of $2-3 \mathrm{~g} /$ bait/dove/day. In fact, the proposed intake level was similar to the actual median consumption registered per pair, which was $4.2 \mathrm{~g}$ of bait/pair/day, assuming that both individuals ate similar amounts. Based on previous aviary evaluations and the feeding behavior of eared doves, we assumed that this amount of 
A
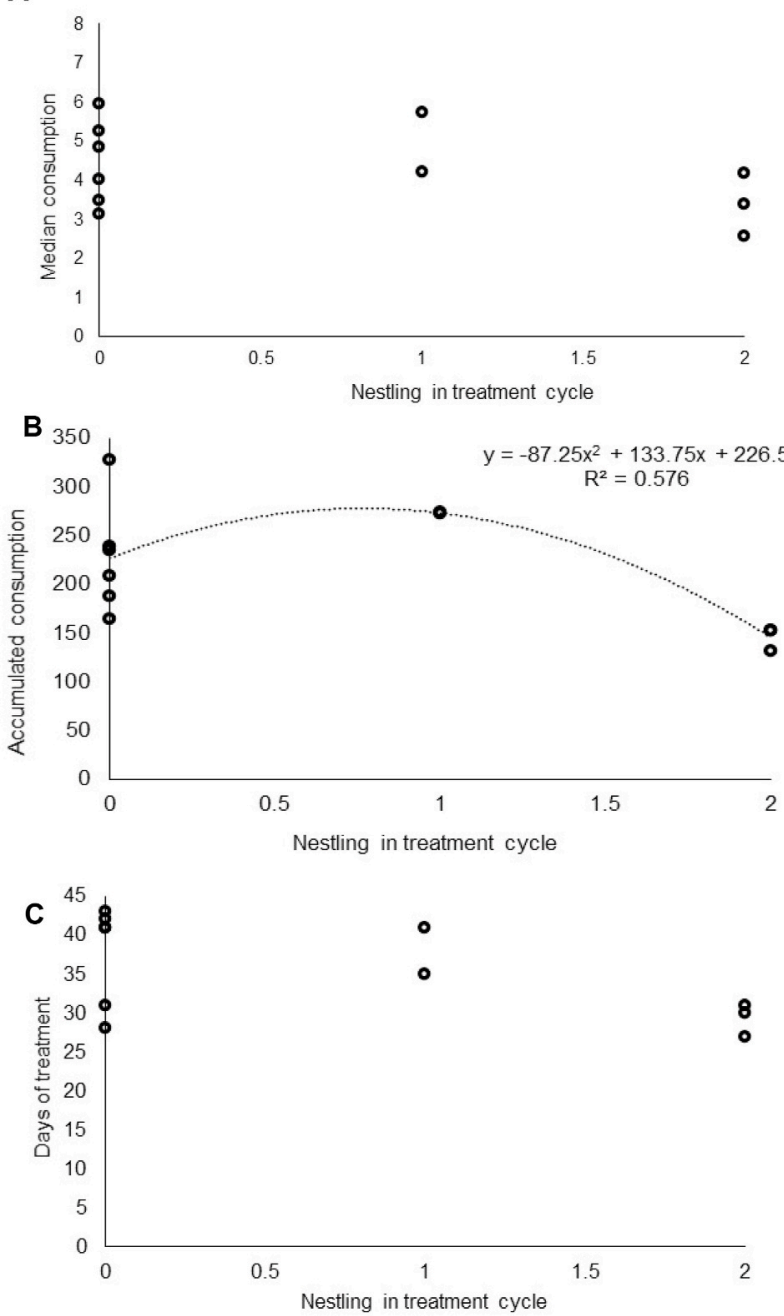

Fig. 3. Associations between the numbers of successful nestlings produced in the treatment phase and contraceptive Ovocontrol ${ }^{\circledR}$ bait consumption variables for the eleven pairs of eared doves (Zenaida auriculata) that ingested the product daily in the morning without any other food alternative. A- Second degree polynomial function with the median consumption per pair. B- Second degree polynomial function with the accumulated consumption of total contraceptive. C- Second degree polynomial function with the number of days that the contraceptive was consumed in the treatment phase. contraceptive would represent a realistic consumption in the field tests.

This study demonstrated that the accumulated consumption was the variable that best explained the contraceptive effect as measured by the number of nestlings. Cumulative consumption rose when doves increased their daily intake of nicarbazin and/or elevated the number of days that birds consumed the contraceptive. The necessary dose of nicarbazin in the blood must be ensured at the time of egg development. DNC may remain in the bird's body and might be metabolized by the liver and excreted within four days. HDP is metabolized faster and is completely eliminated in less than $24 \mathrm{~h}$ through the urine (Johnston et al., 2001). Therefore, nicarbazin should be ingested prior to ovulation and through continuous consumption in subsequent days (or weeks) in order to maintain the target blood concentration of nicarbazin at ovulation. In studies with chickens (Gallus gallus), four doses and different delivery periods were tested, the highest dose (150 ppm in feed) reduced the reproductive rate by $33 \%$ after six days of treatment and by $85 \%$ after 14 days of treatment (Johnston et al., 2001). The lowest doses ( $0.25 \mathrm{ppm}$ in feed) tested by Johnston et al. (2001) reduced chick production by $67 \%$ after 14 days of nicarbazin treatment. In that study, DNC values measured in blood were higher at the end of the treatment. Therefore, the lowest doses that chickens consumed for 14 days were more effective than the highest doses consumed for six days. To obtain an effect on reproductive variables, it might be necessary to attain an effective dose of contraceptive consumption prior to ovulation. Thus, it is necessary that the population of birds returns repeatedly to consume the contraceptive bait. It would be informative to conduct a study with individually identified eared doves to ensure this occurs on a regular basis.

Our results showed that pairs of doves that produced one nestling consumed the same amounts of contraceptive in the treatment phase than pairs with no nestling. This fact could be related to the experimental design. Individual consumption was estimated from two birds in a cage and perhaps in some situations, the male consumed more contraceptive bait than the female. The contraceptive effect in males has not been studied as thoroughly as in females. Yoder et al. (2006a) reported a decrease in the number of sperm cells with high intracellular calcium content in male doves consuming nicarbazin compared to control males. These results indicated that the nicarbazin may act as a weak calcium channel blocker in the male dove's testis.

Contraceptive consumption by doves varied among weeks. This might be explained by the feeding of nestlings in the cage. They were in the parent cage for two weeks during pre-treatment period. Even though the intake of maintenance feed was increased, the consumption of contraceptive increased markedly in the days prior to the removal of the nestlings from the cage. The nestlings were fed by the parents and therefore, the demand for maintenance feed and contraceptive increased as the nestlings grew.

We also confirmed that the effect of nicarbazin was reversible. When

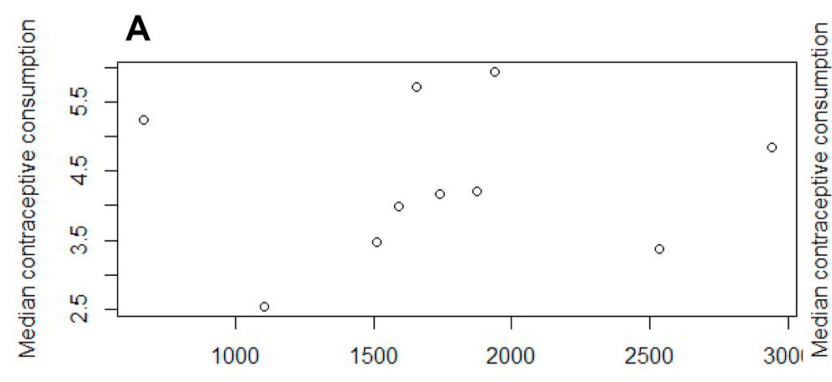

DNC in fecal matter

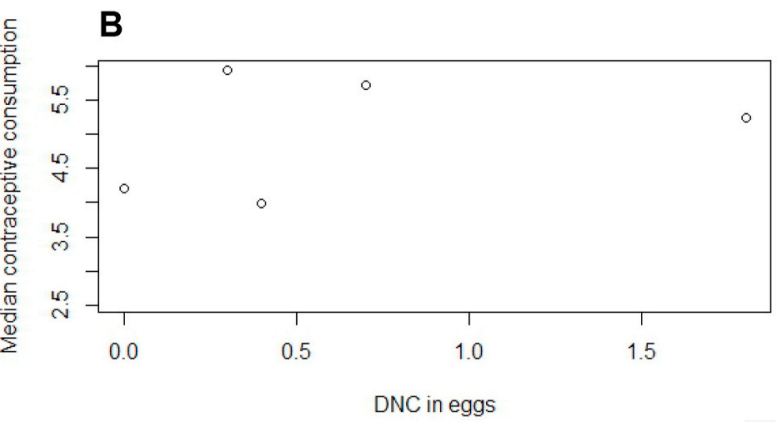

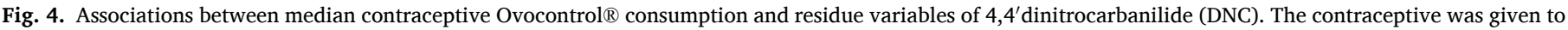

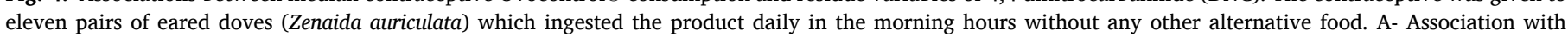

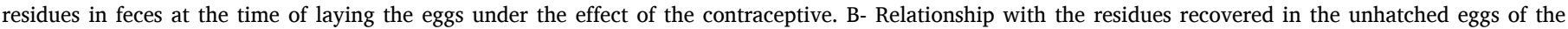
treatment phase; when the pairs laid two nonviable eggs, they were analyzed together ( $\mathrm{n}=5$ pairs, total 8 eggs). 
the treatment ceased, the reproductive variables did not differ between the recovery and pre-treatment phases. Similar findings were reported by Avery et al. (2008); Yoder et al. (2006b) and Johnston et al. (2001), consistent with the high excretion rates of nicarbazin.

Nevertheless, the number of viable eggs and number of successful nestlings were lower in the recovery phase compared to the pretreatment phase. This could be explained by an effect of the reproductive seasonality of the doves, rather than by a residual effect of the contraceptive (Maldonado et al., 2020). Although evidence has been reported that at similar latitudes, eared doves can reproduce throughout the year, greater breeding activity was observed in spring and summer (Bucher and Orueta, 1977). In addition, male testosterone plasma concentrations were analyzed throughout the year by Maldonado et al. (2020), who found two peaks in October and February and the lowest testosterone plasma concentrations between March and July. In our study, five dove pairs completed their treatment phase and started the recovery in March and April. This overlap with the season of less intense breeding activity may have contributed to the fact that three of these pairs were the ones producing an unviable egg each.

Measuring contraceptive consumption requires experiments in captivity. In our study some pairs did not reproduce normally in captivity. The percentage of pairs that laid at least one egg was $71 \%$, and $52 \%$ produced at least one successful nestling. We found no published accounts of eared doves bred in captivity, although there are reports in Zenaida macroura (Buerger et al., 1983) and Zenaida asiatica (Burkepile et al., 2002). Buerger et al. (1983) does not mention the percentage of pairs that did not reproduce. In a three-year study, Burkepile et al. (2002) found a mean of $75 \%$ pairs laid at least one egg and $59 \%$ had at least one successful nestling.

We did not find an association between contraceptive residues in unhatched eggs and contraceptive consumption. The concentrations we obtained from unhatched eggs were lower than those reported by Johnston et al. (2001) and Avery et al. (2008). This difference could be explained because in some cases only the shell could be analyzed. The birds tended to remove the egg from the nest and sometimes the entire yolk could not be recovered. In addition, there were pairs that consumed contraceptive but did not produce eggs. Therefore, their data were not included in the analysis.

The association between contraceptive residues in feces and contraceptive consumption was not significant. In our study, the contraceptive consumption was variable among days and weeks, which might indicate that residues from a one-day sample of fecal matter may be a poor indicator of the average consumption of the entire period. Yoder et al. (2006b) found that ducks eliminated the active ingredient in a non-uniform way when they ingested it in a single daily dose. Therefore, the rate of excretion would depend on whether they consumed small amounts of contraceptive or a large intake in a short time. In addition, we did not collect some feces that were in inaccessible places in the cage (nest, floor). Future studies should consider plasma blood residues that might better correlate with contraceptive consumption, as reported by Avery et al. (2008). These authors used DNC from blood samples collected at the end of the treatment period after the second egg was laid. However, the critical time at which egg viability occurs might have occurred weeks before sample collection. In addition, drawing blood provides stress for the eared doves which could have negative effects on the reproductive success of the pair.

\section{Conclusion}

Nicarbazin is an effective contraceptive in caged eared doves. To achieve this goal, a intake of $4.2 \mathrm{~g}$ of bait/day (approximately $2 \mathrm{~g} /$ bird) is necessary in captivity. The use of nicarbazin baits should begin before ovulation and continue until the stage of egg development in order to maintain an effective titer in the blood. The contraceptive effect proved reversible and reproductive variables returned to pre-treatment levels when the treatment ended.
We recognize that our results are preliminary, but they provide a solid step toward development of an effective management alternative for this economically important species. Our next set of experiments will measure contraceptive bait acceptance and consumption in the field, followed by evaluation of the efficiency of the contraceptive in reducing reproductive variables in eared dove breeding colonies. Future research might also include a cost-benefit analysis (e.g., Peer et al., 2003) of contraceptive use for reducing crop losses by eared doves.

\section{Management implications}

Since dove population size is regulated by the amount of available food (Bucher, 1986), this population management measure must be accompanied by other techniques directed at reducing food availability for the birds. Practices such as closing food storage sites or protect them using a bird proof net when not used to feed livestock might aid. In our opinion, the use of an oral contraceptive would be complementary tool to the existing measures to mitigate the damage caused by this species. It should be investigated within the context of an integrated crop protection strategy, including reduction of available food, prevention measurements and protection at the farm level.

\section{Declaration of competing interest}

The authors declare that they have no known competing financial interests or personal relationships that could have appeared to influence the work reported in this paper.

\section{Acknowledgments}

This study was financial by Agricultural Technology Promotion Fund (grant number FPTA $\mathrm{N}^{\circ} 352$ ) in National Research Agricultural Institute (INIA). Lourdes Olivera had a doctoral fellowship from National Research and Innovation Agency (ANII- grant numbers POS_NAC_2016_1_130028). We want to thank Erick Wolf from Innolytics LLC (USA) for donating the contraceptive product. We are grateful to General Directorate of Agricultural Services (MGAP) for its support in the experiments. We thank Dr. Elly Navajas for reviewing the manuscript and for her valuable contributions.

\section{References}

Albonetti, P., Marletta, A., Repetto, I., Sasso, E., 2015. Valutazione retrospettiva dell'efficacia della nicarbazina (Ovistop $\left.{ }^{\circledR}\right)$ per il contenimento e la riduzione delle popolazioni di Columba livia var. domestica nella città di Genova. Vet. Ital. 51, 63-72. https://doi.org/10.12834/VetIt.337.1448.3.

Avery, M.L., 2014. Feasibility of Applying Contraception for Reducing Crop Damage by Avian Pest Species in Uruguay - Final Report Michael L . Avery. PhD US Department of Agriculture National Wildlife Research Center.

Avery, M.L., Keacher, K.L., Tillman, E.A., 2008. Nicarbazin bait reduces reproduction by pigeons (Columba livia). Wildl. Res. 35, 80-85. https://doi.org/10.1071/WR07017.

Bishop, J.D., McKay, H.V., Parrott, D., Allan, J., 2003. Review of international research literature regarding the effectiveness of auditory bird scaring techniques and potential alternatives. Dep. Food Rural Aff. 1-52.

Bou, N., Dardanelli, S., Olivera, L., Tellechea, G., Addy Orduna, L., Canavelli, S., Rodríguez, E., 2016. Development of a method for assessing damage caused by birds in sprouting soybean in commercial crops. IDESIA 34, 67-74. https://doi.org/ 10.4067/S0718-34292016005000036.

Bruggers, R.L., Rodriguez, E., Zaccagnini, M.E., 1998. Planning for bird pest problem resolution: a case study. Int. Biodeterior. Biodegrad. 42, 173-184. https://doi.org/ 10.1016/S0964-8305(98)00046-8.

Bucher, E.H., 1986. The influence of changes in regional land-use patterns on Zenaida Dove populations. Granivorous birds Agric. Landsc. 291-303.

Bucher, E.H., Orueta, A., 1977. Ecología de la reproducción de la paloma Zenaida auriculata. Ecosur 4, 157-185.

Bucher, E.H., Ranvaud, R.D., 2006. Eared dove outbreaks in South America : patterns and characteristics. Acta Zool. Sin. 52, 564-567.

Bucher, E.R., Bonino, E.E., Di Tada, I., 1981. Criterios para determinar edad y sexo en la paloma torcaza (Zenaida auriculata). Neotropica 27, 151-157.

Buerger, T.T., Mirarchi, R.E., Lisano, M.E., 1983. Effects of lead shot ingestion on captive mourning with a Perkin-Elmer atomic absorption. J. Wildl. Manag. 1-8. 
Burkepile, N.A., Hewitt, D.G., Waggerman, G.L., Small, M.F., Hellgren, E.C., 2002. Effects of methyl parathion on white-winged dove productivity and reproductive behavior. J. Wildl. Manag. 66, 202. https://doi.org/10.2307/3802886.

Bynum, K.S., Eisemann, J.D., Weaver, G.C., Yoder, C.A., Fagerstone, K.A., Miller, L.A., 2007. Nicarbazin OvoControl G bait reduces hatchability of eggs laid by resident Canada geese in Oregon. J. Wildl. Manag. 71, 135-143. https://doi.org/10.2193/ 2005-603.

Carlson, J.C., Stahl, R.S., DeLiberto, S.T., Wagner, J.J., Engle, T.E., Engeman, R.M., Olson, C.S., Ellis, J.W., Werner, S.J., 2018. Nutritional depletion of total mixed rations by European starlings: projected effects on dairy cow performance and potential intervention strategies to mitigate damage. J. Dairy Sci. 101, 1777-1784. https://doi.org/10.3168/jds.2017-12858.

Cuckler, A.C., Malanga, C.M., Basso, A.J., O'Neill, R.C., 1955. Antiparasitic Activity of Substituted Carbanilide Complexes 122, 244-255.

Dardanelli, S., Fandiño, B., Calamari, N.C., Canavelli, S.B., Zaccagnini, M.E., 2016. ¿Eligen las palomas y cotorras los lotes de soja (Glycine max) en emergencia? Un caso de estudio en agroecosistemas de Entre Ríos, Argentina. Rev. Mex. Biodivers. 87, 1308-1314. https://doi.org/10.1016/j.rmb.2016.09.006.

De Mey, Y., Demont, M., 2012. Bird damage to rice in Africa: evidence and control. In: Wopereis, M.C.S., Johnson, D.E., Ahmadi, N., Tollens, E., Jalloh, A. (Eds.), Book: Realizing Africa's Rice Promise Chapter: 19 Publisher: CABI Publishing Editors, pp. 241-249. https://doi.org/10.1079/9781845938123.0241.

Fagerstone, K.A., Miller, L.A., Eisemann, J.D., O’Hare, J.R., Gionfriddo, J.P., 2008 Registration of wildlife contraceptives in the United States of America, with OvoControl and GonaCon immunocontraceptive vaccines as examples. Wildl. Res. 35, 586-592. https://doi.org/10.1071/WR07166.

Fagerstone, K.A., Miller, L.A., Killian, G., Yoder, C.A., 2010. Review of issues concerning the use of reproductive inhibitors, with particular emphasis on resolving humanWildlife conflicts in North America. Integr. Zool. 5, 15-30. https://doi.org/10.1111/ j.1749-4877.2010.00185.x.

Feare, C.J., 1991. Bird Pests in Argentina and Uruguay. Consultant's Report on Nonlethal Control: Chemosterilants. Unpublished consultancy report for the Food and Agriculture Organization (FAO), Rome Italy.

Johnston, J.J., Britton, W., Macdonald, A., Primus, T., Goodall, M., Yoder, C., Miller, L. Fagerstone, K., 2001. Quantification of plasma and egg 4, 4 ' dinitrocarbanilide (DNC) residues for the efficient development of a nicarbazin-based contraceptive for pest waterfowl. Pest Manag. Sci. 58, 197-202. https://doi.org/10.1002/ps.439.

Kirkpatrick, J.F., Turner, J.W., 1985. Chemical fertility control and wildlife management. Bioscience 35, 485-491. https://doi.org/10.2307/1309816.

Klosterman, M.E., Linz, G.M., Slowik, A.A., Bleier, W.J., 2011. Assessment of bird damage to sunflower and corn in north Dakota. 14th Wildl. Damage Manag. Conf. 119-123.

Linz, G.M., Bucher, E.H., Canavelli, S.B., Rodriguez, E., Avery, M.L., 2015. Limitations of population suppression for protecting crops from bird depredation: a review. Crop Protect. 76, 46-52. https://doi.org/10.1016/j.cropro.2015.06.005.

Maldonado, L., Tempesti, T.C., Somoza, G.M., Peluc, S.I., Valdez, D.J., 2020. Reproduction in the Eared Dove: an exception to the classic model of seasonal reproduction in birds? Zoology 140, 125769. https://doi.org/10.1016/j. zool.2020.125769.

Olivera, L., Tellechea, G., Lamanna, A., Banchero, G. E., Fernandez, E., Rodríguez, E.N., In press. Diagnóstico y cuantificación de la problemática causada por la concentración de aves en un tambo estabulado de Uruguay. Rev. Argentina Prod. Anim.

Olivera, L., Rodríguez, E., Pereyra, S., Sawchik, J., Ceretta, J., Banchero, G., 2020. Evaluación de la aceptación de distintas presentaciones de un contraceptivo oral en palomas torcazas. Rev. FAVE - Ciencias Agrar. 19, 7-18.
Otieno, N.E., 2019. Economic impact of predatory piscivorous birds on small-scale aquaculture farms in Kenya. Aquac. Reports 15, 100220. https://doi.org/10.1016/j. aqrep.2019.100220.

Peer, B.D., Homan, H.J., Linz, G.M., Bleier, W.J., 2003. Impact of blackbird damage to sunflower: bioenergetic and economic models. Ecol. Appl. 13, 248-256. https://doi. org/10.1890/1051-0761(2003)013[0248:IOBDTS]2.0.CO, 2.

Robles, J., Jacobsen, S.E., Rasmussen, C., Otazu, V., Mandujano, J., 2003. Plagas de aves en quinua (Chenopodium quinoa Willd.) y medidas de control en el Perú central, vol. 43. Revista Peruana de Entolomogía, pp. 147-151.

Rodríguez, E., Bruggers, R.L., Bullard, R., Cook, R., 1995. An integrated strategy to decrease eared dove damage in sunflower crops. Natl. Wildl. Res. Cent. Repellents Conf. 409-421.

Rodríguez, E., Tiscornia, G., 2002. Evaluación de alternativas de control de la cotorra (Myiopsitta monachus), Serie FPTA. FPTA N ${ }^{\circ}$ 08, SerieMontevideo, Uruguay.

Rodríguez, E., Tiscornia, G., Olivera, L., 2011. Diminución del daño por aves en pequeños predios. Estrategia de disminución del daño por aves en pequeños predios de alto valor utilizando métodos no contaminantes. Serie FPTA INIA, Montevideo, Uruguay, ISBN 9789974383227.

Scalora, A.S., Casmuz, A.S., Cazado, L.E., Aralde, M.R., Aybar Guchea, Matías, Gómez, M., Fadda, L.A., Colledani Toranzo, G.A., Fernández, J.L., Vera, M.A., Gómez, C.H., Gastaminza, G.A., 2013. Evaluación del daño ocasionado por la paloma torcaza (Zenaida auriculata) en el cultivo de soja, en las campañas 2011/2012 y 2012/2013. Publicación Espec. - Estac. Exp. Agro-Industrial Obispo Colombres.

Stahl, R.S., Johnston, J.J., 2002. High-performance liquid chromatography-based determination of nicarbazin excretion in waterfowl. J. Chromatogr. B Anal. Technol. Biomed. Life Sci. 775, 103-108. https://doi.org/10.1016/S1570-0232(02)00165-4.

Stahl, R.S., VerCauteren, K.C., Kohler, D., Johnston, J.J., 2003. 4,4'-dinitrocarbanilide (DNC) concentrations in egg shells as a predictor of nicarbazin consumption and DNC dose in goose eggs. Pest Manag. Sci. 59, 1052-1056. https://doi.org/10.1002/ ps.746.

Tellechea, G., Rodríguez, E., 2016. Prospección del uso de métodos contraceptivos en dos aves plaga de agricultura de Uruguay. Unidad de Comunicación y Transferencia de Tecnología, ISBN 978-9974-38-368-5.

Tracey, J., Bomford, M., Hart, Q., Saunders, G., Sinclair, R., 2007. Managing Bird Damage to Fruit and Other Horticultural Crops. Bureau of Rural Sciences. Australian Government, Canberra.

Vitti, D., Zuil, S., 2012. Evaluaciones del daño generado por aves en girasol. Voces y ecos 29, 11-13.

Werner, S.J., Avery, M.L., 2017. Chemical repellents. Ecol. Manag. Blackbirds North Am. 135-158 https://doi.org/10.4324/9781315156439-8.

Yoder, C.A., Andelt, W.F., Miller, L.A., Johnston, J.J., Goodall, M.J., 2004. Effectiveness of twenty, twenty-five diazacholesterol, avian gonadotropin-releasing hormone, and chicken riboflavin carrier protein for inhibiting reproduction in coturnix quail. Poultry Sci. 83, 234-244. https://doi.org/10.1093/ps/83.2.234.

Yoder, C.A., Avery, M.L., Keacher, K.L., Tillman, E.A., 2007. Use of DiazaCon ${ }^{\mathrm{TM}}$ as a reproductive inhibitor for monk parakeets (Myiopsitta monachus). Wildl. Res. 34, 8-13. https://doi.org/10.1071/WR06069.

Yoder, C.A., Graham, J.K., Miller, L.A., 2006a. Molecular effects of nicarbazin on avian reproduction. Poultry Sci. 85, 1285-1293. https://doi.org/10.1093/ps/85.7.1285.

Yoder, C.A., Graham, J.K., Miller, L.A., Bynum, K.S., Johnston, J.J., Goodall, M.J., 2006b. Evaluation of nicarbazin as a potential waterfowl contraceptive using mallards as a model. Poultry Sci. 85, 1275-1284. https://doi.org/10.1093/ps/ 85.7.1275.

Yoder, C.A., Miller, L.A., 2006. Avian contraceptive tools: one size does not fit all. Proc. Vertebr. Pest Conf. 22 https://doi.org/10.5070/v422110263. 